\title{
A survey of dairy calf management practices in some producing regions in
} Brazil

\author{
Glauber dos Santos ${ }^{1}$, Carla Maris Machado Bittar ${ }^{2}$ \\ 1 Universidade de São Paulo, Escola Superior de Agricultura "Luiz de Queiroz", Programa de Pós-graduação em Ciência Animal e Pastagens, \\ Piracicaba, SP, Brasil. \\ 2 Universidade de São Paulo, Escola Superior de Agricultura “Luiz de Queiroz", Departamento de Zootecnia, Piracicaba, SP, Brasil.
}

\begin{abstract}
This study aimed to characterize the Brazilian dairy calves raising systems through a survey of major aspects of animal husbandry. One hundred seventy-nine producers and/or technicians were interviewed. The questionnaire addressed issues related to the management of the dry cow and the newborn, nutritional management of the liquid-feeding phase, housing, and health management. A third of newborn calves stay with their mothers for more than $24 \mathrm{~h}$ after delivery, and only $56 \%$ of the calves receive colostrum within the first $8 \mathrm{~h}$ of life. Four out of ten producers allow the calf to suckle colostrum directly from the mother. Regarding the liquid diet, 44 and 35\% of the farms provide marketable milk and discard milk for the calves, respectively. It was possible to identify several areas of improvement in the raising system; for instance, greater attention could be given to dry cows and the monitoring of births and to the establishment of adequate protocols to evaluate colostrum quality and feeding management.
\end{abstract}

Key Words: colostrum, raising system, transfer of passive immunity, weaning

\section{Introduction}

High mortality and/or morbidity rates of newborn animals, caused mainly by failures in the transfer of passive immunity, are the main causes for this inefficiency in the dairy activity. However, the identification of inadequate handling practices and improvements in the processing of colostrum feeding can reduce mortality and consequently production costs.

Several factors can cause failures in passive immunity transfer, some of which are linked to the animal, both cows and newborns; others are linked to human factors such as producers and employees. With relation to the cow, factors can be linked to the calving number, breed, volume of colostrum produced, extension of the dry period, and presence of mastitis, all of which can influence this transfer (Robison et al., 1988; Machado Neto et al., 1995). The newborn, on the other hand, should have the ability to consume and to absorb the colostrum constituents in adequate amounts (James et al., 1983; Losinger and Heinrichs, 1995), which is reduced over time after birth.

In several countries, some studies have already been conducted to understand how producers raise replacement

Received March 21, 2015 and accepted July 8, 2015

Corresponding author: carlabittar@usp.br

http://dx.doi.org/10.1590/S1806-92902015001000004

Copyright (C) 2015 Sociedade Brasileira de Zootecnia. This is an Open Access article distributed under the terms of the Creative Commons Attribution License (http://creativecommons.org/licenses/by/4.0/), which permits unrestricted use, distribution, and reproduction in any medium, provided the original work is properly cited. animals (Machado Neto et al., 2004; Kehoe et al., 2007; Vasseur et al., 2010; Walker et al., 2012). Through these studies, it was possible to provide information on handling regarding the feeding and health management of the calves, all of which contribute to a reduction in the animal mortality and morbidity rates.

As regards the data from Brazilian systems, there is a scarcity of studies that characterize the production of dairy calves; in the literature, only one study focused on issues related to colostrum feeding, but in a specific state of Brazil (Machado Neto et al., 2004). Despite the wealth of information, the study did not reveal more detailed information about the production of dairy calves considering dry cows and weaning. Unlike countries such as the USA, which maintain studies about characterization of milk production systems in order to understand and to identify problems, Brazil does not have a government program with this purpose. Thus, the objective of this study was to characterize the current dairy calf management practices in important dairy productions states (Minas Gerais, Paraná, and São Paulo), which can help with the understanding of challenges on dairy calf raising, labor training opportunities, and direction of future research.

\section{Material and Methods}

The questionnaire was developed based on information in the literature and field experiences and addressed issues related to property identification (area, type of production 
system, property size), management of dry cows (drying criteria, location of the maternity paddock, dry-cow and close-up cow diet), calving management (reproduction technique, pen observation, calving assistance, percentage of assisted calving), newborn handling (first aid, time until colostrum intake, volume of colostrum provided, colostrum storage, serum protein monitoring), calf nutrition management (feeding method, type of liquid diet, volume of milk offered, criteria of weaning), housing (type of housing, disinfection area, bedding), and health management (main vaccinations and diseases).

One hundred seventy-nine (179) producers and/or technicians from properties that were willing to participate in the study, located in the states of Minas Gerais (97/54\%), São Paulo (49/27\%), Paraná (28/16\%), and others (Ceará (2), Goiás (2), and Distrito Federal (1)) (5/3\%), which produced a daily milk volume of 105,236 L (35\%), 92,870 L (31\%), 97,574 L (32\%), and 8,059 L (3\%), respectively, were interviewed. In addition to the region, the properties were classified according to the volume of daily milk production into one of the following categories: $<200 \mathrm{~L}$ (44/23\%), 201 to $700 \mathrm{~L}(58 / 32 \%)$, and $>701 \mathrm{~L}(77 / 44 \%)$. The interview was conducted based on a semi-structured questionnaire that was applied by a unique interviewer. The interviewees in some cases were the handlers of the calves, although on other occasions the owner and/or technician of the farm were the ones who answered the questionnaire, depending on the availability of both. Data collection occurred in November of 2012 at a technical event (61 interviews) and other interviews (118) occurred at the farm from July to November of 2013. The contact with these producers occurred through the industry, dairy cooperatives, and association of producers.

Data were summarized by simple or grouped descriptive statistics according to the production level to facilitate presentation, comparison, and discussion of the results. The non-probability sampling (judgmental sampling) was conducted while considering the availability and quality of data from producers.

\section{Results and Discussion}

Almost a quarter of the interviewed properties produce up to $200 \mathrm{~L} / \mathrm{d}$ of milk; $32 \%$ between 201 and $700 \mathrm{~L}$; and $44 \%$ produce more than $701 \mathrm{~L}$ of milk/d. According to IBGE (2006), the national average milk production is lower than $100 \mathrm{~L}$. For the majority of these properties, milk was the main source of income, although other activities have been developed such as horticulture and egg production. With relation to the volume of milk produced, the greatest production class $(>700 \mathrm{~L})$ represented $88 \%$ of all milk producers. Although the profitability of different production systems has not been studied, research related to Brazilian milk production costs have suggested evidence of the occurrence of gains with increased production scale (Lopes et al., 2007). Tradition and experience of the producers in milk production can be interpreted based on the amount of time the producers have been involved in the activity. The majority of the producers have been involved in dairy activities for more than 15 years; $24 \%$ of these producers have been involved in livestock production for more than 25 years, thereby suggesting some expertise. However, we found that in many properties, the advanced age of the producer and the lack of a direct successor are factors that limit long-term investments in the dairy industry. This finding correlates with those of SEBRAE (2005), which concluded that the Brazilian dairy livestock has a characteristic population of older and traditional producers who accepted lower profitability, a condition not accepted by their heirs.

The predominant production system was grazing with supplementation (66\%), followed by indoor housing $(25 \%)$, and grazing with no supplementation (8\%) (Table 1). Santos and Lopes (2014) compared the profitability of these two types of systems (semi-feedlot $\times$ feedlot) on farms producing milk in the state of Minas Gerais and concluded that the immobilized money to produce one liter of milk is US\$ 340.07 and US\$ 368.87, respectively. A large difference in investments is evident in the immobilized land

Table 1 - Characteristics of milk production systems by herd size (small, <200 L/day; medium, 201 to $700 \mathrm{~L} /$ day; large, >700 L/day)

\begin{tabular}{lcccc}
\hline & $<200$ & 201 to 700 & $>700$ & All herds \\
\hline Grazing with supplementation, \% & 71 & 91 & 52 & 66 \\
Grazing with no supplementation, $\%$ & 29 & 6 & 47 & 8 \\
Indoor housing, \% & 0 & 2 & 23.18 & 17.49 \\
Production/lactating cow, L/day & 9.29 & 469.5 & $3,286.80$ & 750 \\
Average daily production, L/day & 146.4 & 210 & 42,000 & $4,830.70$ \\
Lowest production, L/day & 40 & 700 & 288,980 & 40.00 \\
Highest production, L/day & 200 & 22,070 & 147 & 316,600 \\
Volume of milk produced, L/day & 5,570 & 37 & & 84 \\
Number of lactating cows & 17 & &
\end{tabular}


for semi-feedlot systems and at the property considering the improvements and equipments for feedlot. The decision to define which production system should be adopted will depend on the ability to produce forage (pasture or silage), personal preference for the system, and the ability to assume financial risks of the producer, since the property capital will have a greater or lower liquidity.

The average milk production among all properties was $1,830.7 \mathrm{~L} / \mathrm{d}$, and varied from 40 to $42,000 \mathrm{~L} / \mathrm{d}$, which indicates a large variation in production among the characterized properties. Paraná State had the highest average productivity per lactating cow $(30.25 \mathrm{~kg})$ due to the type of production system (total feedlot), specialized animal, and favorable climate (temperate climate). Nevertheless, the maximum daily production per cow $(42.31 \mathrm{~kg}$ ) was observed in the Minas Gerais State, a region that presented the lowest average productivity $(14.11 \mathrm{~kg})$ due to utilization of non-specialized animals and a lack of feed supplementation at the majority of the properties. In another survey, Minas Gerais State presented an average milk production per lactating cow of $8.10 \mathrm{~kg} /$ day (SEBRAE, 2005). The average milk production in the present study, despite being the lowest among all regions in the study, is above the average milk production of the state; however, this fact does not reduce the responsibility of the manager to constantly search for ways to improve this indicator.

The main criteria for dry-off lactating cows were the expected date of calving (61\%), low milk production (34\%), and the occurrence of sanitary problems (5\%). Also, as the size of the property increased, the period between dry-off and the date of calving increased due to the breed pattern of the cows ( Gyr $\times$ Holstein crossbred) and the lower persistence of lactation. Generally, animals with a greater percentage of genes from the Gyr breed have a shorter lactation period (Glória et al., 2006). When the criteria for drying was daily milk production, the minimum milk production to maintain lactating cows was $5 \mathrm{~L}$ for $59 \%$ of the properties, and between 15 and $20 \mathrm{~L}$ for $13 \%$ of the interviewees. The extension of the dry period has an important impact on the cash flow of the property and the performance of the animals because it interferes with the relationship between productive (lactating cows) and unproductive animals (growing animals and dry cows) (Santschi et al., 2011), affects the incidence of metabolic problems in the post-calving period (Bachman and Schairer, 2003), influences mastitis prevention (Green et al., 2007), and also affects colostrum production (Machado Neto et al., 1995).

The maternity paddock is located close to the barn, an employee's house, or the owner's house for 43, 32, and $11 \%$ of the properties, respectively. It is interesting to observe that for $14 \%$ of the properties the paddock is located in a remote location, far from the normal traffic of people, which can lead to problems when a cow needs aid to calve, a fact that can lead to dystocia. According to the literature, this type of calving has a negative correlation with the mortality of calves and can affect the absorption of colostrum, interfere with body temperature regulation, and generate trauma that affects the cardiopulmonary system of the calf (Meyer et al., 2001; Lombard et al., 2007). The importance of helping the cow during calving requires low financial investments when it comes to ensuring adequate training of labor concerning the decision-making process and how to assist the calving process, as these are most effective at reducing the occurrence of unnecessary dystocia. In the present study, no correlation between dystocia and mortality could be established due to lack of necessary information.

Of the main reproduction techniques that are utilized to fertilize cows, artificial insemination is adopted by $59 \%$ of the properties, followed by natural service $(36 \%)$ and controlled service $(4 \%)$. In properties that produce more than $700 \mathrm{~L} / \mathrm{d}$, the adoption of artificial insemination has a success rate of $79 \%$. Moreover, $75 \%$ of the interviewees considered calving ease when choosing which semen to utilize, a factor that is related to the rate of dystocia, which negatively affects the health of the cow and the calf (Dhakal et al., 2013). Dystocia is more common in primiparous cows because of their smaller size; the birth is considered to be a dystocia when there is a calving delay or when the cow finds it difficult to calve (Meyer et al., 2001). Dystocia can cause hypoxia, significant acidosis, interfere with the absorption of colostrum, and reduce the survival of newborns (Lombard et al., 2007). However, the lack of human intervention in dystocia can lead to the death of both cow and calf.

For 55 and 3\% of the interviewees, observation of the maternity pen to identify the occurrence of calving takes place often during the day and the night, respectively. During the night, for $62 \%$ of the interviewees, no observations of the maternity pen took place. It is important that people visit the maternity pen so that they can help cows that have difficulty calving and also to perform first-aid measures for newborns. To avoid the contamination of newborns with bacteria present in the maternity, the shortest time possible in this location is recommended. However, there are studies that show positive effects based on the interaction between the cow and her calf during the first hours of life of the newborn (Paranhos da Costa et al., 2007; Toledo et al., 2007). Moreover, contact between the handler and the calf 
lead to the identification of some anomaly for both cow and calf.

Four out of ten properties remove the newborn from the maternity pen within the first $8 \mathrm{~h}$ of life (Table 2), thereby suggesting that $60 \%$ of newborns may consume colostrum in an uncontrolled manner. In these situations, the colostrum intake in an acceptable amount and time can be reduced since the newborn vigor, concentration of immunoglobulin, udder conformation, and maternal ability will have direct correlations with intake (Franklin et al., 2003).
Treating the navel was the main practice performed after birth, followed by colostrum feeding and removal of the membranes (Table 2). However, some of the properties (7\%) treat the navel incorrectly or with an inadequate product; for instance, they may use ointment or a solution that kills screwworms when an iodine solution should be utilized. Failures in treating the navel can generate infection and hernias, cause omphalitis and myiasis, while also allowing pathogenic microorganisms to cause an ascending infection (Place et al., 1998). Data from the USDA (2008)

Table 2 - Management of newborn and colostrum feeding practices by herd size

\begin{tabular}{|c|c|c|c|c|}
\hline & $<200$ & 201 to 700 & $>700$ & All herds \\
\hline Separation from the dam & \multicolumn{4}{|c|}{ 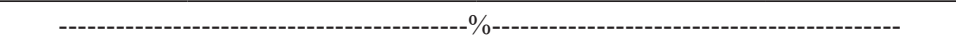 } \\
\hline$<8 \mathrm{~h}$ & 18 & 36 & 51 & 40 \\
\hline 8 to $24 \mathrm{~h}$ & 18 & 31 & 36 & 31 \\
\hline 24 to $48 \mathrm{~h}$ & 18 & 10 & 7 & 10 \\
\hline$>48 \mathrm{~h}$ & 47 & 23 & 7 & 19 \\
\hline \multicolumn{5}{|l|}{ Early care of the newborn } \\
\hline Removal of membranes & 5 & 7 & 11 & 9 \\
\hline Colostrum intake & 26 & 32 & 43 & 37 \\
\hline Dipping navels with iodine & 53 & 52 & 44 & 48 \\
\hline Other & 16 & 9 & 3 & 7 \\
\hline \multicolumn{5}{|c|}{ Time to receive first colostrum, diurnal calving } \\
\hline$<4 \mathrm{~h}$ & 22 & 31 & 53 & 40 \\
\hline 4 to $8 \mathrm{~h}$ & 3 & 14 & 22 & 16 \\
\hline 8 to $12 \mathrm{~h}$ & 16 & 12 & 12 & 13 \\
\hline Dam & 59 & 43 & 14 & 31 \\
\hline \multicolumn{5}{|c|}{ Time to receive first colostrum, overnight calving } \\
\hline$<4 \mathrm{~h}$ & 0 & 10 & 17 & 12 \\
\hline Other morning & 37 & 46 & 63 & 53 \\
\hline Dam & 63 & 44 & 19 & 35 \\
\hline \multicolumn{5}{|l|}{ Colostrum storage } \\
\hline No & 92 & 81 & 64 & 74 \\
\hline Yes & 8 & 19 & 36 & 26 \\
\hline Refrigerator & 0 & 22 & 3 & 7 \\
\hline Frozen & 100 & 78 & 97 & 93 \\
\hline Stored without refrigeration & 0 & 0 & 0 & 0 \\
\hline \multicolumn{5}{|l|}{ Method of thawing colostrum } \\
\hline Water bath & 100 & 100 & 94 & 95 \\
\hline Microwave & 0 & 0 & 0 & 0 \\
\hline Room temperature & 0 & 0 & 6 & 5 \\
\hline \multicolumn{5}{|l|}{ Quality control } \\
\hline No & 100 & 98 & 80 & 89 \\
\hline Yes & 0 & 2 & 20 & 11 \\
\hline Colostrometer & 0 & 0 & 71 & 67 \\
\hline Visual analysis & 0 & 100 & 29 & 33 \\
\hline \multicolumn{5}{|l|}{ Colostrum feeding method } \\
\hline Bucket & 3 & 8 & 12 & 9 \\
\hline Bottle & 11 & 37 & 63 & 46 \\
\hline Esophageal tube & 0 & 0 & 6 & 3 \\
\hline Dam & 86 & 56 & 20 & 42 \\
\hline \multicolumn{5}{|c|}{ Colostrum volume fed in the first feeding } \\
\hline $2 \mathrm{~L}$ & 3 & 10 & 32 & 20 \\
\hline $3 \mathrm{~L}$ & 17 & 31 & 33 & 29 \\
\hline $4 \mathrm{~L}$ & 0 & 4 & 9 & 6 \\
\hline$>4 \mathrm{~L}$ & 0 & 4 & 9 & 6 \\
\hline Dam & 80 & 51 & 17 & 39 \\
\hline \multicolumn{5}{|c|}{ Monitoring of serum protein in calves } \\
\hline No & 100 & 100 & 97 & 98 \\
\hline Yes & 0 & 0 & 3 & 2 \\
\hline
\end{tabular}


show that navel problems are the fourth factor that causes deaths in calves, with digestive and respiratory problems and calving complications as the first three factors.

Supplying calves with colostrum during the first $4 \mathrm{~h}$ of life is performed by $40 \%$ of the properties in daytime calving; however, this percentage falls to $12 \%$ of the properties in nighttime calving (Table 2). Such a difference could be due to the absence of people in the maternity pen during the night, or due to the far distance of the maternity pen from the employee's house. The cost:benefit ratio of implementing a night watch system as well the motivation of the employee to identify calving and to offer colostrum to the calf during nighttime birth should be compared with the survival and performance of these newborns. In the majority of the properties with nighttime calving, the supply of colostrum is performed in the morning on the following day (53\%) (Table 2). Vasseur et al. (2010), in the province of Quebec, Canada, found that $94.8 \%$ of newborns received their first meal of colostrum within the first $6 \mathrm{~h}$ of life and that $40.9 \%$ received colostrum within the first $2 \mathrm{~h}$ of life. However, the authors commented that this time interval is based on the moment when the calf was first seen and not necessarily on the lifetime of the newborn, thereby suggesting that the time could be greater than $6 \mathrm{~h}$.

The greater the milk production of the property, the greater was the percentage of those that provided colostrum in a period less than four hours, which was possibly due to the greater specialization and care associated with calf rearing. The time from calving to the intake of colostrum is a factor that correlates negatively with the transfer of passive immunity for calves, as the greater the time interval, the lower the efficiency of the absorption of immunoglobulin (Kehoe et al., 2007). In the first $6 \mathrm{~h}$ of life, the macromolecules that arrive in the intestine are absorbed intact without undergoing denaturation. However, with increasing age, the efficiency of absorption decreases, being greatly reduced 16 to $18 \mathrm{~h}$ after calving, with no absorption occurring after 24 h (Johnson et al., 2007; Godden, 2008).

In $53 \%$ of the properties, the calves from nighttime calving received the colostrum only in the morning of the following day. Moreover, in 31 and 35\% of the properties, the colostrum intake occurs directly from the cow when the calving happens during the day and night, respectively (Table 2). These findings contribute to an expectation of low performance in animals from these production systems. This percentage of properties that leave the calf to consume the colostrum from the cow is very close to the value of $36 \%$ that has been observed on US farms (USDA, 2008), although it is greater than the $15.6 \%$ presented by Vasseur et al. (2010) in Canadian herds. When newborns consume colostrum directly from the cow, the time of ingestion, the volume ingested and the colostrum quality cannot meet the requirements in order to guarantee the correct transfer of passive immunity. The success of the programs of colostrum intake and, consequently, the adequate transfer of passive immunity depend on three factors that may not be controlled when the animal consumes colostrum from the cow (Weaver et al., 2000; Godden, 2008).

In $74 \%$ of properties, the storage of surplus colostrum did not occur; this percentage was greater at properties with a lower daily milk production (Table 2 ). When storage is performed, the main form of storage is freezing followed by refrigeration. The bank of colostrum is an important alternative to maintain high quality colostrum on the property, as there is a difference in the concentration of immunoglobulin in the colostrum produced by cows (Weaver et al., 2000), and also there may be a low amount of colostrum production by some animals. Among the properties that store colostrum, only $11 \%$ evaluate the quality before storage and $33 \%$ of them perform a visual analysis, while $67 \%$ utilize a colostrometer (Table 2). In the United States, $13 \%$ of the producers that store colostrum measure the colostrum quality (USDA, 2008). The estimate of the colostrum quality by using the colostrometer is an easy and cheap method that can be utilized on any farm (Vasseur et al., 2009).

The majority of the properties provide colostrum via a bottle ( $46 \%$ ), followed by colostrum intake from the mother $(42 \%)$, a bucket $(9 \%)$, and via an esophageal tube $(3 \%)$ (Table 2). When calves are fed colostrum via a bottle, it is possible to offer feedings with a known quality and volume, although it is necessary to ensure adequate cleaning of this apparatus. The direct intake from the mother can result in an intake of inadequate quality, volume, and/or time, thus contributing to high failure rates of the transfer of passive immunity.

For $29 \%$ of properties, the volume of colostrum that is provided in the first meal to newborns is three liters; for $20 \%$ of the properties this volume is two liters; and only $6 \%$ of the interviewees provide four or more liters of colostrum (Table 2). The recommendation is that a $43-\mathrm{kg}$ calf should receive $100 \mathrm{~g}$ of IgG in the first meal (Davis and Drackley, 1998); the volume needed will be dependent on the initial concentration of IgG in the colostrum. The better the colostrum quality, the less volume is needed to meet the requirements of the newborn and to guarantee adequate transfer of passive immunity. However, Faber et al. (2005) showed that the intake of $4 \mathrm{~L}$ of colostrum compared to $2 \mathrm{~L}$ improved the performance and future milk production. A way to evaluate the efficiency of the supply of colostrum 
is by monitoring the serum protein of newborns by using a refractometer of brix or of protein (Deelen et al., 2014). These tools have a very low cost, even though $98 \%$ of producers did not monitor the serum protein. The identification of problems in acquiring adequate passive immunity did not allow for the correction of the problem in the calf, but helps to identify failures in the process and the need to train employees that are responsible for this task.

The artificial liquid-feeding system is adopted by $65 \%$ of the producers, while yet another $35 \%$ of the systems still use natural feeding (Table 3). It is noteworthy that a large part of these $35 \%$ has daily milk productions lower than $200 \mathrm{~L}$, raise crossbred animals, and milk cows that are allowed to be sucked by their calves. However, $15 \%$ of dairy milk production systems that produce above $700 \mathrm{~L}$ have been found to have suckling calves with their mothers. With natural milk feeding, it is not possible to offer known amounts of milk to calves; thus, in most of the systems the nutritional requirements of the animal cannot be met, which in turn limits performance (Davis and Drackley, 1998). Moreover, the milk intake can be different among contemporary animals, and the formation of homogeneous lots in terms of weight and height is made more difficult with differences in performances. The adoption of the natural milk feeding system makes it difficult to plan the daily milk volume to be commercialized, and can result in greater income variation for the producer.

For the artificial milk feeding system, the bucket is the main apparatus utilized to supply the liquid diet (71\%), followed by the bottle (24\%) and by the nipple bucket (3\%) (Table 3). Only 2\% utilize an automatic feeding system and $1 \%$ the gang feeding method using containers. The supply of liquid diet in the bucket is the most widely adopted because of its easy cleaning and the lowest time for the consumption by the calves. However, the supply of the liquid diet in a bucket does not meet the calf's need to suckle, thus increasing the occurrence of non-nutritive suckling (Veissier et al., 2002) and cross-suckling among calves (Jensen and Budde, 2006), mainly when they are grouped.

Regarding the constitution of the liquid diet, $44 \%$ of the properties choose to provide marketable milk to calves; waste milk is the second most utilized diet among the interviewees $(35 \%)$; and the use of milk replacer is adopted only by $13 \%$ (Table 3 ). We observed that among properties with a lower daily milk production, the main constituent of the liquid diet is marketable milk, since the majority of these calves suckle from their own mothers. However, at properties with greater milk production, the waste milk is the main constituent of the liquid diet due to the representation of this component in the production systems. Unfortunately, the use of waste milk in the feeding of calves is considered advantageous for the production system according to several technicians and producers. The supply of waste milk, for example, prevents the discard of waste milk in the environment as pollution and enables the commercialization of a greater volume of milk. However, it increases the risk of causing bacterial resistance due to the supply of sub-doses of antibiotics in the milk of treated cows, in addition to the greater occurrence of diarrhea due to the high bacterial load in the waste milk. Also, the supply of waste milk is associated with the possibility of the inoculation of mastitis pathogens when calves are grouped-raised and perform cross-feeding. Good-quality milk replacer results in animal similar to that associated with marketable milk (Hill et al., 2007); and it can present an economic advantage depending on the price paid per liter of milk. However, it separates the times associated with supplying the liquid diet and milking, thereby eliminating the dependence of calf production on the milking parlor.

The volume of liquid diet that calves receive in the first 30 days of life is lower or equal to $4 \mathrm{~L} / \mathrm{d}$ for $41 \%$ of the interviewed properties, and $28 \%$ of the properties offer $6 \mathrm{~L} / \mathrm{d}$ to calves in the same period (Table 3 ). However, $23 \%$ of the properties still allow calves to suckle directly from their mothers, independently from the age of the calves. According to the NRC (2001), the nutrients that are found in $4 \mathrm{~L}$ of milk are enough to meet the requirements for maintenance and a daily weight gain of approximately $350 \mathrm{~g}$. When the volume of milk increases to $6 \mathrm{~L} / \mathrm{d}$, in addition to meeting the requirements for maintenance, nutrients provide a daily gain of approximately $630 \mathrm{~g}$. However, when calves suckle directly from their mothers, the volume of milk that is available to the calf depends on the intent of the milker when it comes to leaving more or less milk for the calf, and the ability of the cow to keep residual milk during the milking, compromising animal performance.

In this study, the practice of offering water on the first day of life occurs in $53 \%$ of the properties, although for $35 \%$ and $15 \%$ of the properties water is provided to calves only from the fifth and tenth days of life, respectively. The supply of water to newborns is important since the first weeks of life because it is highly related to the concentrate intake (Kertz et al., 1984). The concentrate is offered to animals from the first day of life for $33 \%$, from the fifth day of life for $38 \%$, and only from the fifteenth day for $19 \%$ of the properties. The supply of concentrate in the diet of calves aims to stimulate rumen development, and therefore adapt the newborn to this component of the diet as soon as possible, allowing for the weaning of the animal (Quigley et al., 1990). 
Roughage is offered to calves on the first day of life by $22 \%$ of the interviewees, while for $31 \%$ of the interviewees the roughage is provided from the fifth day of life. Also, the roughage is offered to calves only after weaning by $22 \%$ of the producers. For $85 \%$ of properties with daily milk production levels below $200 \mathrm{~L}$, some type of roughage

Table 3 - Nutritional management of calves by herd size

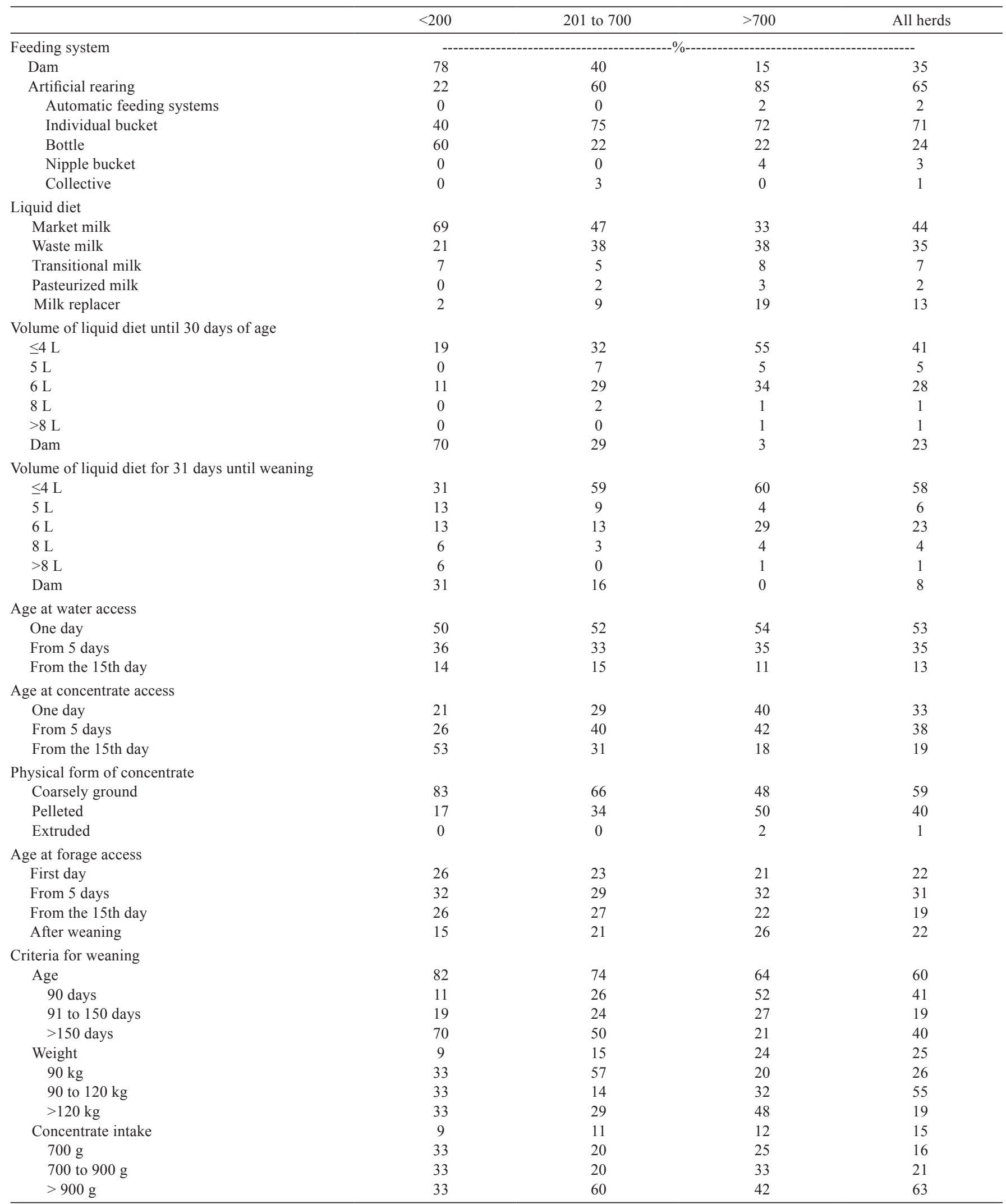


source is offered to calves; this also occurs for $74 \%$ of properties with daily milk production levels above $700 \mathrm{~L}$. In other words, the supply of roughage during the liquidfeeding phase is predominant in the majority of properties. According to Drackley (2008), the replacement of milk with a solid diet (grains and forages) is a factor that contributes to the reduction of mortality and favors an increase in the body weight gain of calves. However, studies have shown that although the roughage intake during the milk-feeding phase for calves favors the rumen physical development (Hill et al., 2008), this slows the rumen papillae growth (Khan et al., 2011) due to the change in the fermentation profile (Sakata and Tamate, 1978). Several studies show that the rumen development with regard to the number and size of papillae that will allow for the absorption of the final products of fermentation contribute to the energy requirements of the animal and depend on the intake of concentrate feedstuffs (Bach et al., 2007; Khan et al., 2011) and not on roughage. In the meantime, the importance of fiber (amount, source, and size) in maintaining rumen health and increasing the performance of the calf during the liquid-feeding phase has been observed in the latest research (Bach et al., 2007; Castells et al., 2012; Terré et al., 2013), mainly for intensive feeding systems.

When asked about the main criteria for weaning calves, for $60 \%$ of the interviewees, the answer was age followed by body weight and concentrate intake (Table 3 ). For $70 \%$ of the properties with daily milk production levels below $200 \mathrm{~L}$, the weaning of calves occurs after more than 150 days; in other words, the adopted criterion age is a function of the lactation of the cow, and not of early weaning. In Canadian herds, Vasseur et al. (2010) found that $66.7 \%$ of the producers also adopted the criterion age to perform calf weaning. Such a finding can be due to the practicality of the operation, since the concentrate intake and body weight need to be routinely monitored. However, the concentrate intake always should be monitored because animals that consume less than $700 \mathrm{~g}$ of concentrate per day (large breeds) have inadequate rumen development at the time of weaning, which can compromise their performance in the next phase (Quigley et al., 1991). Other concerns are economic in nature because the liquid diet represents 60 to $70 \%$ of the variable costs during the liquid-feeding phase (Santos and Lopes, 2014).

For the producers that choose the age at which to wean calves, the majority (41\%) perform the weaning when the animal is 90 days old. However, for $40 \%$ of the interviewees, the age at weaning is greater than 150 days, which can greatly increase the cost of replacement heifers (Table 3). The profile of properties that wean calves at less than 90 days tends to be properties that are more specialized in milk production, using European breeds that reach high performance and have a reduction in the age at the first calving of the heifers. On the other hand, the production systems that wean calves older than 150 days are those in which crossbreeds are utilized (Holstein $\times$ Gyr) and the productivity tends to be low.

The main housing systems are individual pen or collective paddocks, followed by collective pen and individual shelters (Table 4), such that $55 \%$ of calves are raised in groups and $45 \%$ individually. When animals are raised individually, there is a reduction in the dissemination of diseases as well as a reduction in the competition for feed (Veissier et al., 2002). However, animals that are raised collectively begin to develop playful, exploratory, and competitive behaviors that will be beneficial in the postweaning phase (Jensen and Budde, 2006). Furthermore, animals that have been raised together have greater behavioral flexibility, which is required in responses to environment changes such as in a mixture of unfamiliar animals in the same group (De Paula Vieira et al., 2010). Individualization allows for the individual control of feed intake and leads to a quicker diagnosis of diseases and other management problems.

For $44 \%$ of the interviewees, shelter change location occurs when there is mud around the shelter; $24 \%$ perform the change weekly, $16 \%$ rarely change the shelter location, $10 \%$ perform the change monthly, and only $5 \%$ were said to move the shelter daily. The need to move shelters periodically is due to the accumulation of feces and urine around the individual shelters, which facilitates the development of bacteria, ammonia, and the presence of flies, which is worse during the hot and humid months of the Brazilian summer.

One out of every five properties did not vaccinate calves against any type of disease; at other properties, the main vaccinations are against blackleg, rabies, leptospirosis, Infectious Bovine Rhinotracheitis/Bovine Virus Diarrhea (IBR/BVD), salmonellosis, and pasteurellosis (Table 4). In the United States (USDA, 2008), the most utilized vaccinations at properties are the following: IBR/BVD (65\%), leptospirosis (63\%), and Bovine Respiratory Syncytial Virus (BRSV) (60\%). The main diseases that affect calves during the liquid-feeding phase are diarrhea, tick fever, pneumonia, and worms (Table 4). For 54\% of the interviewees, diarrhea affects calves between 8 and 15 days of age, a period during which there is a reduction in the passive immunity of the newborn. In US herds (USDA, 2008), the main diseases that affect calves daily are diarrhea, respiratory problems, and infection of the umbilicus.

R. Bras. Zootec., 44(10):361-370, 2015 
Table 4 - Housing and health management of calves by herd size

\begin{tabular}{|c|c|c|c|c|}
\hline & $<200$ & 201 to 700 & $>700$ & All herds \\
\hline \multicolumn{5}{|l|}{ Housing system } \\
\hline Collective stall & 22 & 33 & 18 & 25 \\
\hline Collective paddock & 28 & 35 & 18 & 30 \\
\hline Individual stall & 17 & 14 & 46 & 30 \\
\hline Individual shelter & 33 & 18 & 18 & 15 \\
\hline \multicolumn{5}{|l|}{ Major vaccines used } \\
\hline Carbuncle & 12 & 39 & 30 & 34 \\
\hline Rabies & 13 & 27 & 13 & 17 \\
\hline Leptospirosis & 13 & 15 & 14 & 13 \\
\hline Infectious Bovine Rhinotracheitis/Bovine Virus Diarrhea & 14 & 8 & 11 & 9 \\
\hline Pasteurella & 15 & 1 & 3 & 2 \\
\hline Salmonella & 16 & 0 & 6 & 4 \\
\hline No vaccine & 17 & 8 & 23 & 19 \\
\hline \multicolumn{5}{|l|}{ Major diseases } \\
\hline Diarrhea & 18 & 42 & 54 & 48 \\
\hline Pneumonia & 19 & 19 & 23 & 22 \\
\hline Tick fever & 20 & 23 & 18 & 21 \\
\hline Worms & 21 & 7 & 3 & 5 \\
\hline Not known & 22 & 9 & 2 & 4 \\
\hline
\end{tabular}

\section{Conclusions}

The calf production systems in important regions of Brazil need to improve some management practices, as many techniques that are recommended to increase the efficiency have not been adopted. Through this study, it was possible to identify several areas that need improvement, mainly the establishment of adequate colostrum feeding protocols as well as the nutrition management during the liquid-feeding phase, with focus on quality and volume of liquid-feeding. It is clear that there is a wide opportunity for milk-replacer adoption and adjustments in the liquidfeeding duration.

\section{Acknowledgments}

We gratefully acknowledge the financial support granted by Fundação de Amparo à Pesquisa do Estado de São Paulo (2012/17740-4).

\section{References}

Bach, A.; Gimenez,A.; Juaristi, J. L. and Ahedo, J. 2007. Effects of physical form of a starter for dairy replacement calves on feed intake and performance. Journal Dairy Science 90:3028-3033.

Bachman, K. C. and Schairer, M. L. 2003. Invited Review: Bovine studies on optimal lengths of dry periods. Journal Dairy Science 86:3027-3037.

Castells, L.; Bach, A.; Araujo, G.; Montoro, C. and Terre, M. 2012. Effect of different forage sources on performance and feeding behavior of Holstein calves. Journal Dairy Science 95:286-293.

Davis, C. L. and Drackley, J. K. 1998. The development, nutrition, and management of the young calf. Iowa State University Press, Ames.
De Paula Vieira, A.; Von Keyserlingk, M. A. G. and Weary, D. M. 2010. Effects of pair versus single housing on performance and behavior of dairy calves before and after weaning from milk. Journal Dairy Science 93:3079-3085.

Deelen, S. M.; Ollivett, T. L.; Haines, D. M. and Leslie, K. E. 2014. Evaluation of a Brix refractometer to estimate serum immunoglobulin $\mathrm{G}$ concentration in neonatal dairy calves. Journal Dairy Science 97:3838-3844.

Denise, S. K.; Robison, J. D.; Scott, G. H. and Armstrong, D. V. 1989. Effects of passive immunity on subsequent production in dairy heifers. Journal Dairy Science 72:52-554.

Dhakal, K.; Maltecca, C.; Cassady, J. P.; Baloche, B.; Williams, C. M. and Washburn, S. P. 2013. Calf birth weight, gestation length, calving ease, and neonatal calf mortality in Holstein, Jersey, and crossbred cows in a pasture system. Journal Dairy Science 96:690-698.

Drackley, J. K. 2008. Calf nutrition from birth to breeding. Veterinary Clinic Food Animal 24:55-86.

Faber, S. N.; Faber, N. E. and McCauley, T. C. 2005. Effects of colostrum ingestion on lactational performance. Professional Animal Science 21:420-425.

Franklin, S. T.; Amaral-Phillips, D. M.; Jackson, J. A. and Campbell, A. A. 2003. Health and performance of Holstein calves that suckled or were hand-fed colostrum and were fed one of three physical forms of starter. Journal Dairy Science 86:2145-2153.

Glória, J. R.; Bergmann, J. A. G.; Reis, R. B.; Coelho, M. S. and Silva, M. A. 2006. Efeito da composição genética e de fatores de meio sobre a produção de leite, a duração da lactação e a produção de leite por dia de intervalo de partos de vacas mestiças Holandês-Gir. Arquivo Brasileiro Medicina Veterinária e Zootecnia 58:1139-1148.

Godden S. 2008. Colostrum management for dairy calves. Veterinary Clinic North American Food Animal Practice 24:19-39.

Green, M. J.; Bradley, A. J.; Medley, G. F. and Browne, W. J. 2007. Cow, farm, and management factors during the dry period that determine the rate of clinical mastitis after calving. Journal Dairy Science 90:3764-3776.

Hill, T. M.; Bateman, H. G.; Aldrich, J. M. and Schlotterbeck, R. L. 2007. Effects of feeding rate of milk replacers and bedding material for calves in a cold naturally ventilated nursery. Professional Animal Science 23:656-664. 
Hill, T. M.; Bateman, H. G.; Aldrich, J. M. and Schlotterbeck, R. L. 2008. Effects of the amount of chopped hay or cottonseed hulls in a textured calf starter on young calf performance. Journal Dairy Science 91:2684-2693.

IBGE - Instituto Brasileiro de Geografia e Estatística. 2006. Censo agropecuário 2006. Rio de Janeiro. 777p. Available at: $<$ http://www.ibge.gov.br/home/estatistica/economia/agropecuaria/ censoagro/2006/>. Accessed on: Jan 1, 2013.

James, R. E.; Polan, C. E. and Cummins, K. A. 1983. Influence of administered indigenous microorganisms on uptake of [iodine125] gamma-globulin in vivo by intestinal segments of neonatal calves. Journal Dairy Science 64:52-61.

Jensen, M. B. and Budde, M. 2006. The effects of milk feeding method and group size on feeding behavior and cross-sucking in group-housed dairy calves. Journal Dairy Science 89:4778-4783.

Johnson, J. L.; Godden, S. M.; Molitor, T.; Ames, T. and Hagman, D. 2007. Effects of feeding heat-treated colostrum on passive transfer of immune and nutritional parameters in neonatal dairy calves. Journal Dairy Science 90:5189-5198.

Kehoe, S. I.; Jayarao, B. M. and Heinrichs, A. J. 2007. A survey of bovine colostrum composition and colostrum management practices on Pennsylvania dairy farms. Journal Dairy Science 90:4108-4116.

Kertz, A. F.; Reutzel, L. F. and Mahoney, J. H. 1984. Ad libitum water intake by neonatal calves and its relationship to calf starter intake, weight gain, feces score, and season. Journal Dairy Science 67:2964-2969.

Khan, M. A.; Weary, D. M. and Von Keyserlingk, M. A. G. 2011. Effects of milk ration on solid feed intake, weaning, and performance in dairy heifers. Journal Dairy Science 94:1071-1081.

Lombard, J. E.; Garry, F. B.; Tomlinson, S. M. and Garber, L. P. 2007. Impacts of dystocia on health and survival of dairy calves. Journal Dairy Science 90:1751-1760.

Lopes, M. A.; Cardoso, M. G.; Carvalho, F. M.; Lima, A. L. R.; Dias, A. S. and Carmo, E. A. 2007. Efeito do tipo de sistema de criação nos resultados econômicos de sistemas de produção de leite na região de lavras (MG) nos anos 2004 e 2005. Ciência Animal Brasileira 8:359-371.

Losinger, W. C. and Heinrichs, A. J. 1995. Dairy operation management practices and herd milk production. Journal Dairy Science 79:506-514.

Machado Neto, R.; Faroni, C. E.; Pauletti, P. and Bessi, R. 2004. Levantamento do manejo de bovinos leiteiros recém-nascidos: desempenho e aquisição de proteção passiva. Revista Brasileira de Zootecnia 33:2323-2329.

Machado Neto, R.; Prado, G. V. B.; Bessi, R. and Hattnher, F. L.1995. Flutuação das proteínas séricas em vacas primíparas e multíparas no período pré-parto. Scientia Agricola 52:158-160.

Meyer, C. L.; Berger, P. J.; Koehler, K. J.; Thompson, J. R. and Sattler, C. G. 2001. Phenotypic trends in incidence of stillbirth for Holsteins in the United States. Journal Dairy Science 84:515-523.

NRC - National Research Council. 2001. Nutrient requirements of dairy cattle. 7th rev. ed. National Academy of Sciences, Washington, DC.
Paranhos da Costa, M. J. R.; Schmidek, A. and Toledo, L. M. 2007. Relações materno-filiais em bovinos de corte do nascimento à desmama. Revista Brasileira de Reprodução Animal 31:183-189.

Place, N. T.; Heinrichs, A. J. and Erb, H. N. 1998. The effects of disease, management, and nutrition on average daily gain of dairy heifers from birth to four months. Journal Dairy Science 81:1042-1050.

Quigley, J. D.; Smith, P. and Heitmann, R. N. 1991. Changes in plasma volatile fatty acids in response to weaning and feed intake in young calves. Journal Dairy Science 74:258-263.

Robison, J. D.; Stott, G. H. and DeNise, S. K. 1988. Effects of passive immunity on growth and survival in the dairy heifer. Journal Dairy Science 71:1283-1287.

Sakata, T. and Tamate, H. 1978. Rumen epithelial cell proliferation accelerated by rapid increase in intraruminal butyrate. Journal Dairy Science 61:1109-1113.

Santos, G. and Lopes, M. A. 2014. Custos de produção de fêmeas bovinas leiteiras do nascimento ao primeiro parto. Ciência Animal Brasileira 15:11-19.

Santschi, D. E.; Lefebvre, D. M.; Cue, R. I.; Girard, C. L. and Pellerin, D. 2011. Economic effect of short (35-d) compared with conventional (60-d) dry period management in commercial Canadian Holstein herds. Journal Dairy Science 94:4734-4743.

SEBRAE - Serviço Brasileiro de Apoio às Micros e Pequenas Empresas. 2005. Diagnóstico da pecuária leiteira do Estado de Minas Gerais em 2005: Relatório de pesquisa. FAEMG, Belo Horizonte.

Terré, M.; Pedrals, E.; Dalmau, A. and Bach, A. 2013. What do preweaned and weaned calves need in the diet: A high fiber content or a forage source? Journal Dairy Science 96:5217-5225.

Toledo, L. M.; Paranhos da Costa, M. J. R.; Titto, E. A. L.; Figueiredo, L. A. and Ablas, D. S. 2007. Impactos de variáveis climáticas na agilidade de bezerros Nelore neonatos. Ciência Rural 37:1399-1404.

USDA. 2008. Dairy 2007. Heifer calf health and management practices on United State dairy operations. USDA-APHIS, Fort Collins, $\mathrm{CO}$

Vasseur, E.; Borderas, F.; Cue, R. I.; Lefebvre, D.; Pellerin, D.; Rushen, J.; Wade, K. M. and De Passillé, A. M. 2010. A survey of dairy calf management practices in Canada that affect animal welfare. Journal Dairy Science 93:1307-1315.

Vasseur, E.; Rushen, J. and De Passillé, A. M. 2009. Does a calf's motivation to ingest colostrum depend on time since birth, calf vigor or provision of heat? Journal Dairy Science 92:3915-3921.

Veissier, I.; De Passillé, A. M.; Després, G.; Rushen, J.; Charpentier, I.; Ramirez, A. R, and Pradel, P. 2002. Does nutritive and nonnutritive sucking reduce other oral behaviors and stimulate rest in calves? Journal Dairy Science 80:2574-2587.

Walker, W. L.; Epperson, W. B.; Wittum, T. E.; Lord, L. K.; RajalaSchultz, P. J. and Lakritz, J. 2012. Characteristics of dairy calf ranches: Morbidity, mortality, antibiotic use practices, and biosecurity and biocontainment practices. Journal Dairy Science 95:2204-2214.

Weaver, D. M.; Tyler, J. W.; Van Metre, D. C.; Hostetler, D. E. and Barrington, G. M. 2000. Passive transfer of colostral immunoglobulins in calves. Journal Veterinary Internal Medicine 14:569-577. 